Kimberly Kay Wiley*

\title{
Leveraging Political Resources: Applying the Advocacy Coalition Framework to the National Coalition Against Domestic Violence
}

https://doi.org/10.1515/npf-2020-0020

Received May 2, 2021; accepted September 25, 2021

\begin{abstract}
As politics becomes increasingly polarized, the value of collective political action becomes more visible and overt. Nonprofit organizations act collectively in pursuit of their policy goals in nearly all aspects of public policy. Understanding how nonprofits borne of social movements engage politically expands our insight into advocacy coalition behavior following seemingly effective social movements. The coalition's leveraging of political resources provides us this insight. This study assesses the policy activities produced or maintained within a U.S. national domestic violence advocacy coalition over its lifetime to determine how and when resources were leveraged. A directed content analysis is conducted on historical data to capture the evolution of coalition activities over a 41-year period. The coalition's emphasis on policy change waned over time as it achieved its policy goals. The coalition then leaned on its largest resources, mobilizable troops, and information to increasingly emphasize policy implementation and evaluation. These findings indicate that when in the policy process coalitions leverage their political resources may be more important than how coalitions leverage resources. Framing nonprofit political activity across the stages of the policy process can open doors to better use of scarce political resources.
\end{abstract}

Keywords: advocacy coalition framework, policy process, content analysis, social movements, domestic violence

\section{Introduction}

As politics becomes increasingly polarized, the value of collective political action becomes more visible and overt. Nonprofit organizations act collectively in pursuit of their policy goals in nearly all aspects of public policy. The advocacy coalition framework (ACF) proposes causal mechanisms for policy change in relation to this

*Corresponding author: Kimberly Kay Wiley, Family, Youth, and Community Sciences, University of Florida, PO Box 110310, Gainesville, Florida, USA, E-mail: kimberlywiley@ufl.edu 
coalition behavior (Jenkins-Smith et al. 2018; Weible 2007; Weible et al. 2011). ACF proposes relationships between mechanisms internally and externally associated with a coalition and the policy process. One key variable in this framework is the coalition's political resources. Formal coalitions maintain relationships with their member nonprofit organizations who serve as mobilizable troops (Wiley, Searing, and Young 2021), which are considered a type of political resource in ACF and a human resource in resource mobilization theory (Edwards and McCarthy 2004). These mobilizable troops engage in the policy process as secondary actors and create a critical mass that drives policy (Jenkins-Smith et al. 2018; Wiley, Searing, and Young 2021; Edwards and McCarthy 2004).

A gap exists in ACF scholarship on how coalitions leverage such political resources (Weible et al. 2011). A closer examination of resources is necessary to individually operationalize and to better understand how and when the coalition's political resources are engaged over time (Jenkins-Smith et al. 2018; Weible, Sabatier, and McQueen 2009). The research question in this study is how do advocacy coalitions leverage their resources to affect public policy?

Van Dyke and Amos argue, "coalitions are a part of all social movements" (2017, p. 11). Social movement and coalition scholarship emphasizes formation and efforts toward policy change. As a social movement evolves into a coalition with formalized organizations, the coalition can maintain the resources of a social movement (people and skillful leaders) (Arnold 2011). The newly formed coalition and its social movement borne nonprofit organizations engage new resources (information and money) developed through their formalization. One can see this evolution in the Battered Women's Movement. A coalition's early resources (people) disperse and its shared belief system adapts with cultural shifts overtime (Kleidman and Rochon 1997; Arnold and Ake 2013). Thus, to secure continued success, the coalition must evolve further by engaging different political resources (Edwards and McCarthy 2004; Van Dyke and Amos 2017; Wiley, Searing, and Young 2021).

Documenting policy shift and discourse evolution as they relate to policy advocacy activities can provide insight into the relationships between formalized advocacy coalitions and policy change, including a better understanding of how coalitions of nonprofit organizations have identified and worked towards achieving their policy goals. Locating the roles of advocacy coalitions in the policy process over time and assessing the resulting policy change can articulate the value of these advocacy activities for the actors involved (Soule and King 2006). To this end, the focus of this research is on policy activities produced or maintained within a U.S. national domestic violence (DV) advocacy coalition, the National Coalition Against Domestic Violence (NCADV). NCADV is a strong case example of ongoing and evolving political engagement since 1978. NCADV is the first and longest lasting formal coalition in gender-based violence policy advocacy. 
The findings indicate that NCADV leveraged its main resource, its individual members and member organizations, to engage in four policy advocacy roles that resemble the heuristic model of the policy process: agenda setting, formulation, implementation, and evaluation. NCADV emphasized agenda setting in its early years, which supports what is already known about social movement behavior and the formation of coalitions (Soule and King 2006). This analysis of NCADV pushes beyond policy adoption. Over the 41-year history agenda-setting efforts were achieved and the coalition adapted its strategy to address each stage in the policy process more equally. Pursuing numerous policies over four decades, the coalition prioritized civil justice, criminal justice, social welfare benefits, and professionalization of services. Their policy efforts shifted towards policy implementation and policy evaluation. This indicates that this coalition harnessed its resources to simultaneously impact public policy in multiple issue arenas in all stages of the policy process. These findings strengthen understanding of the mobilization of coalition resources and the argument that when in the policy process coalitions deploy their resources matters more than how they leverage their resources. Understanding how social movement borne nonprofits engage politically beyond simple agenda setting expands our insight into coalition behavior following seemingly effective social movements.

\section{Policy Advocacy in Social Movement Borne Nonprofits}

Nonprofit organizations in the U.S. are limited in their political activity by their funding choices and Internal Revenue Service (IRS) designation (Lobbying n.d.). Federal funding prohibits lobbying activities and private donors can restrict political activity (Libby 2012; Smith 2007). A nonprofit may legally use their resources for legislative advocacy in other ways such as, (1) pay for membership to an organization that will advocate on its behalf, (2) create a separate entity with a more appropriate IRS code, and (3) file for H Election allowing the organization to use a portion of its revenue towards political activities (Measuring Lobbying Activity: Expenditure Test n.d.). These restrictions explain why nonprofits may feel limited in their ability to advocate on behalf of their clients and why they may choose collective action through coalition building (Wiley, Searing, and Young 2021; Wiley and Berry 2018). Nonprofits may look for other ways to engage in the policy conversation that do not jeopardize their funding. Social movement borne nonprofits, like DV shelters, rape crisis centers, substance abuse clinics, and independent 
living centers, approach political advocacy as "resistance maintenance" (Majic 2014, p.). ${ }^{1}$ Their approach is street-level policy advocacy-independently within their bureaucratized organizations and collectively with sister organizations (Majic 2014). If the nonprofit's policy efforts are focused on day-to-day interactions with the people they serve, that leaves little time for traditionally viewed policy advocacy. Yet, this activity plays an essential role in the policy process.

According to ACF, nonprofits may work within advocacy coalitions alongside other policy issue stakeholders to push for policy change reflecting their shared policy beliefs (Jenkins-Smith et al. 2018). In response to the limiting nature of the heuristic policy process model, ACF emerged to address the more realistic complexity of policy activities. The framework is useful in this study, because ACF articulates coalition behavior in relationship to policy change (Weible et al. 2011). Understanding how nonprofit collective activity continues beyond the policy adoption stage in the heuristic model can be articulated through the components of ACF. One can operationalize theoretical explanations in terms of these day-today interactions to better understand advocacy coalition behavior. For instance, victim advocacy organizations, such as DV shelters or rape crisis centers, engage in policy advocacy at two levels. These nonprofits advocate for public policy change at the local, state, and national legislative levels, benefitting their (1) service recipients and (2) their organizations. What makes this type of nonprofit unique is how the employees also engage in personal advocacy at the street-level. Employees advocate individually for their service recipients because the service recipients benefit from criminal justice, civil, and social welfare policy fought for by these policy actors (Edwards and McCarthy 2004; Majic 2014; Wiley 2020; Wiley and Berry 2018). Applying ACF to this behavior can help explain how these advocacy coalitions engage across policymaking venues and deploy their political resources (Jenkins-Smith et al. 2018).

In order to locate where institutional rules offer an advantage over their opponents, coalitions shop for policy arenas addressing their individual policy needs (Pralle 2003). Multiple policy arenas can be relevant to a single coalition depending on the complexity of a policy issue. Coalition activities may also shop their policy efforts in legislative, administrative, and judicial venues choosing the ones most friendly to their policy needs (Jones and Jenkins-Smith 2009). Coalitions tackling complex policy issues are strategic and often tactical in their deployment of political resources because of this multiplicity of venues for policy activity (Nohrstedt 2011).

1 Majic labels these organizations that develop out of social movements by activists. They often offer health or human services related to the political issue at hand. They receive government funding to provide these community-based services (2011). 
Making sense of the mobilization of coalition resources leads to unanswered questions in ACF literature (Jenkins-Smith et al. 2018; Weible 2007). Since the development of ACF, scholars have called for further operationalization and hierarchical categorization of six categories of coalition resources: formal legal authority to make policy decisions, public opinion, information, mobilizable troops, financial resources, and skillful leadership (Jenkins-Smith et al. 2018; Nohrstedt and Weible 2010; Sabatier and Weible 2007; Weible et al. 2011). Several scholars have attempted to answer Sabatier \& Weible's question, "What is the role of ... resources ... in coalition membership, behavior, stability, and strategies?” (2007, p. 209). Coalition resources have played a role in policy change during policy stalemates (Ingold 2011; Wiley, Searing, and Young 2021) and determining the appropriate for venue shift (Albright 2011; Jones and Jenkins-Smith 2009; Nohrstedt 2011; Wiley, Searing, and Young 2021). Nohrstedt found greater leverage in terms of strength and power was achieved by choosing the right coalition resources rather than the amount or size of the resources (2011). Wiley, Searing, and Young found an interdependence between the use of information and mobilizable troops (2021). Information directed the activity of the mobilizable troops in engaging in the most effective policy venue, whether legislative or judicial. There is no evidence that one resource is more important than another. Rather choice in resource mobilization is driven by circumstance.

\subsection{Social Movements and Formalization}

Social movements and their child nonprofits are wealthy in one political resource: mobilizable troops (VanDyke and Amos 2017). Social movements do not die upon formalization of new organizations. Instead, the organizations shift to resistance maintenance or political activity within coalitions and the streetlevel (Arnold 2011; Edwards and McCarthy 2004; Majic 2011; VanDyke and Amos 2017). These nonprofits engage their troops in three types of political activities: oppositional implementation, community engagement through service provision, and claims-making through knowledge production (Majic 2011). NCADV is an example of a social movement borne nonprofit that engages as a principal coalition actor on behalf of street-level organizations, individuals, and formal policy actors (Wiley and Berry 2018). This coalition engages in claims-making activity by engaging their wealth of mobilizable troops to advocate in all stages of the policy process on behalf of the social movement and the formalized coalition.

Coalitions must make sure that policy wins at the legislative or judicial level are reflected in the implementation stage, suggesting that timing is important and strategic for coalitions. Individually, direct service providers use discretion to 
make sense of the latent meaning of written policy as street-level bureaucrats. Coalitions do not always stop their advocacy efforts once a policy is adopted, rather coalition-level policy outcomes may continue at the street-level through their nonprofit organizations. This study assessed the deployment of coalition resources over the history of an advocacy coalition across policy venues and policy arenas to better understand these activities.

\subsection{National Coalition Against Domestic Violence}

NCADV provides a strong case for how an advocacy coalition leverages scarce resources over time in effort to impact public policy. Though numerous other organizations spun off NCADV and emerged independently, NCADV has been the single most consistent actor over the four-decade history of the Battered Women's Movement in the U.S. The first DVAOs established as nonprofit organizations were opened in the late 1970s and early 1980s. NCADV was the first to respond to the policy demands and training needs of these new nonprofit managers.

This dues-paying membership coalition consists of locally-based nonprofit organizations, state DV coalitions, and individuals. Through this nested model, the Coalition formally represents the interests of its stakeholders through policy channels and programmatic development (Arnold 2011). NCADV and its members share policy beliefs across time securing and strengthening the formalized coalition (Van Dyke and Amos 2017) since its incorporation in 1983. NCADV is representative of the unitary policy subsystem advocating for victims of DV, though not the only player in the subsystem.

Trust and accountability in social movements are strengthened through ongoing and meaningful, interpersonal interactions (Van Dyke and Amos 2017). NCADV has hosted an in-person meeting biannually since its inception facilitating meaningful member interactions. NCADV's political activity over the history of the coalition is documented through this meeting, which also serves as a conference venue for its members to gather and interact. The meeting initially served as a call for unity between advocates to demand policy change in Washington, DC. The event grew each time to reach over 1000 attendees in recent meetings and was attended by policy subsystem leaders, policy authors, legislative advocates, and street-level victim advocates. The political agenda and activities for each of these stakeholders is documented in the programs for these national events. The street-level workers, such as case managers, victim advocates, and counselors, were changemakers in this arena of public policy. These street-level workers also served as conference panelists and workshop leaders. Because NCADV has historically provided leadership and a pulse on DV service 
provision, their biannual meetings are consistently well-attended by leaders in the organizational field and staff of state, local, and national DVAOs. The large attendance reflects NCADV's role in supporting these member and nonmember organizations through policy advocacy and the dependence of actors on this formalized coalition member.

The Coalition's earliest mission was,

To provide leadership in developing a feminist model for programs working to empower women who have been battered, to provide national communication and sharing network among all grassroots battered women's shelters, groups, organizations and individual workers, and to form a national powerbase around battered women's issues and other important issues affecting women. NCADV seeks to involve all women regardless of age, race, color, creed, sexual/affectional orientation, marital status, social or economic status, disability or geographic location (National Coalition Against Domestic Violence 1982).

Over its history the mission has formally expanded and contracted as demanded by its members. Today, it is a concise two sentences that articulate its role in larger society.

Our mission is to lead, mobilize and raise our voices to support efforts that demand a change of conditions that lead to domestic violence such as patriarchy, privilege, racism, sexism, and classism. We are dedicated to supporting survivors and holding offenders accountable and supporting advocates. (National Coalition Against Domestic Violence 2019).

Deep core policy beliefs of this coalition over time are evidenced in these two mission statements: DV is rooted in societal-level oppression and collective action is imperative for change. NCADV uses their biannual meetings to coordinate the actions of its members towards shared policy goals and policy beliefs and provide a space for working out ideological differences as they arise (Arnold 2011). NCADV provides a strong case for analysis through the Advocacy Coalition Framework and heuristic policy process framework due to the coalition's (1) 41-year history; (2) continual, intensive engagement with all levels of public policy across multiple policy issues; and (3) uniform documentation of its policy activities and political resource usage spanning its entire existence.

\section{Research Design}

The history of the NCADV provides a useful case for answering the research question, how do advocacy coalitions leverage their resources to affect public policy? This longitudinal, empirical analysis of one coalition offers analytic generalizability, rather than statistical generalizability (Yin 2014; Nowell and 
Albrecht 2019). A qualitative investigation will support a data-driven inquiry into why and how this coalition behaves (Nowell and Albrecht 2019). The coalition documented four-decades of political activity, allowing for an analysis of its internal behavior over time. Thus, the case articulates a valuable evolution of advocacy coalition behavior.

\subsection{Data: Historical Documentation of Political Activity}

The author conducted a directed content analysis of historical documentation to capture the evolution of coalition activities led by NCADV (Hsieh and Shannon 2005). NCADV preserved 18 historical documents, each 4-150 pages long, which archive over four decades of agendas and descriptions of conversations held between leading advocates and activists working with U.S. policymakers to develop policy solutions to DV. Policy advocacy efforts were chronicled in this formal communication between advocates and activists in the field at the NCADV bi-annual conference.

The NCADV biannual meeting agendas were rich sources of data (Bowen 2009) as they provide a looking glass into a tool used by NCADV to broaden the agenda that advocates on The Hill and in the DVAO classify as current and relevant. ${ }^{2}$ Within the biannual meeting agendas, the author examined workshop titles and descriptions, rather than plenary presentations, as they offered the highest level of engagement and discussion between conference attendees, where information is both provided and solicited. In this series of 18 biannual meetings, the number of small group meetings or "workshops" (training sessions, panels, roundtable discussions) ranged from 40 to 179 workshops at each event, with a mean of 107 and a total of 1924 workshops. In total, the data consisted of 18 whole documents, representing a 41-year period with 1924 individual codable texts. A timeline of events with dates, locations, and titles is provided in Table 1. The data were scanned and uploaded in .pdf format to NVivo qualitative analysis software.

2 This data presented one major national DV Coalition's perspective of the narratives at hand. The data did not include opposing positions, such as fathers' or men's rights groups who oppose legislation like VAWA (Dragiewicz 2008; Rosen, Dragiewicz, and Gibbs 2009), supporters of marital exemptions to sexual assault laws (i.e., married parties are exempt from laws prohibiting sexual assault), or public apologists for celebrities or leaders charged with abuse of their partners. The biannual meetings include workshops that respond to the opposing policy narratives, but do not include the voices of the opposition themselves. 
Table 1: NCADV biannual meetings 1978-2019.

\begin{tabular}{|c|c|c|c|c|}
\hline $\begin{array}{l}\text { Event } \\
\text { number }\end{array}$ & Year & City & Title of event & $\begin{array}{r}\text { Total } \\
\text { workshops }\end{array}$ \\
\hline $\begin{array}{l}\text { Planning } \\
\text { Meeting }\end{array}$ & 1978 & Portland, OR & $\begin{array}{l}\text { National Coalition Against Domestic } \\
\text { Violence Steering Committee Meeting }\end{array}$ & 0 \\
\hline $1 \mathrm{st}$ & 1980 & $\begin{array}{l}\text { Washington, } \\
\text { DC }\end{array}$ & $\begin{array}{l}\text { First National Conference Against Domes- } \\
\text { tic Violence }\end{array}$ & 40 \\
\hline 2nd & 1982 & Milwaukee, WI & End Violence in the Lives of Women & 150 \\
\hline $3 r d$ & 1986 & St. Louis, MO & $\begin{array}{l}\text { The Battered Women's Movement: Build- } \\
\text { ing a Non-Violent World }\end{array}$ & 179 \\
\hline 4th & 1988 & Seattle, WA & $\begin{array}{l}\text { The Battered Women's Movement } \\
\text { Bringing the Vision Home }\end{array}$ & 125 \\
\hline 5 th & 1990 & Amherst, MA & $\begin{array}{l}\text { The Battered Women's Movement in Ac- } \\
\text { tion ... } 1990 \text { and Beyond }\end{array}$ & 141 \\
\hline 6th & 1994 & St. Paul, MN & Many Voices One Vision & 126 \\
\hline 7th & 1996 & Charleston, SC & Remember and Act & 109 \\
\hline 8th & 1998 & Denver, CO & $\begin{array}{l}\text { Twenty Years of Putting Our Hands } \\
\text { Together hearts, hands, roots, wings }\end{array}$ & 156 \\
\hline 9th & 2000 & Portland, OR & Envisioning Our Future: Peace With Justice & 123 \\
\hline 10th & 2002 & Kissimmee, FL & $\begin{array}{l}\text { The "Herstory" of Our Future: Creating } \\
\text { Social Change }\end{array}$ & 112 \\
\hline 11th & 2004 & Denver, CO & Radical Organizing for Change & 94 \\
\hline 12th & 2006 & Atlanta, GA & Organizing for Collective Power & 126 \\
\hline 13th & 2008 & $\begin{array}{l}\text { Washington, } \\
\text { D.C. }\end{array}$ & $\begin{array}{l}\text { Building Grassroots Leadership for Social } \\
\text { Justice }\end{array}$ & 96 \\
\hline 14th & 2010 & Anaheim, CA & Changing Faces of the Movement & 104 \\
\hline 15th & 2012 & Denver, CO & $\begin{array}{l}\text { Preserving Our Roots While Looking to the } \\
\text { Future }\end{array}$ & 104 \\
\hline 16th & 2016 & Chandler, AZ & Voices United & 52 \\
\hline 17th & 2018 & Providence, RI & Voices Rising & 38 \\
\hline 18th & 2019 & $\begin{array}{l}\text { Washington, } \\
\text { DC }\end{array}$ & Voices in Action & 48 \\
\hline
\end{tabular}

\subsection{Content Analysis and Coding}

The author employed document analysis to make sense of the activities and onedirectional dialogue between presenters and their audience, where the expert describes the workshop's goals, topic, format, and intended audience (Bowen 2009). This type of analysis "entails finding, selecting, appraising (making sense of), and synthesizing" formal and informal communication recorded in written form (Bowen 2009, p. 1281). Unlike discourse analysis and hermeneutic inquiry, this 
study captured the manifest nature of the language, rather than interpretations illuminating latent meaning. Directed content analysis of these documents allowed the author to begin with a prescribed coding schema and add new codes as new themes emerged (Hsieh and Shannon 2005).

The author reviewed the entire set of documents from a previous study and created a codebook based on this first pass through the data and the review of literature. First, a set of codes was developed that represented the stages of the policy process (agenda setting, formulation, implementation, and evaluation) and related policy issues, such as stalking, human trafficking, immigration, protective orders. The author identified patterns of specific policies and public agencies (i.e., Violence Against Women Act or VAWA (1994), Temporary Assistance for Needy Families or TANF (1996), mandatory arrest laws, Department of Justice). An iterative coding approach was necessary as new codes emerged in each document, requiring multiple rounds of coding to capture emergent themes throughout the dataset. Workshop descriptions were identified as related to a public policy and then coded for stage in the policy process, policy issue, and policy or federal department name. Coding occurred systematically at the sentence-level. See the Appendix for an example of the coding schema.

\subsection{Ensuring Credibility}

The data was atypical for an ACF study. Data used in ACF studies is often not generated internally by coalition actors reflecting only their perceptions, like these biannual meeting programs. ACF investigations on coalition resources typically include analysis of externally generated perceptions, like news stories, or internally generated data like long interviews with stakeholders. Interviews allow for investigation of the actor's decision-making, like in Weible's stakeholder analysis of the 1999 California Marine Life Protection Act (2007; Pierce et al. 2017).

Though not the norm, the historical documents used in this study proved to be the most credible data for this longitudinal analysis (Nowell and Albrecht 2019; Onwuegbuzie and Leech 2007). First, newspapers would be unable to capture the depth of the engagement between a coalition and its members. As news reporting is often limited to reporting the interaction of coalition actors (and not internal actions) while valuable for answering some questions, these data are insufficient for understanding the internal deliberations that precede coalition action-such as how and when these coalitions deploy political resources. Due to the age of the half 
of the events included in the study, interviews with attendees risks unreliability due to loss of detailed firsthand accounts (Creswell 2012; Onwuegbuzie and Leech 2007). Additionally, interviews would risk observational bias and illusory correlation because such a large number of actors engaged in this event (Onwuegbuzie and Leech 2007). The workshops descriptions were written by the presenters and submitted to the coalition for review months in advance. This data offers strong evidence that these workshop descriptions document both how the presenters thought about and articulated their ideas at that time.

Two research assistants aided in coding the large dataset. Coding comparison tests were conducted before formal coding began in order to ensure the reliability of the codebook. The codebook include codenames, definitions, and examples to ensure internal credibility in coding (Onwuegbuzie and Leech 2007). Then the team manually coded the workshop descriptions over a six-week period. Five biannual meeting agendas were coded by both students and the author and were used for weekly coding comparisons. The research assistants coded the remaining 13 programs independently and intermittently between coding comparison tests. Four rounds of comparisons were conducted. Coding was in agreement at a rate of $95 \%$ or higher indicating strong agreement in coding. The NVivo coding comparison tool helped us efficiently locate disagreements. To settle disagreements, the team compared the manifest and latent content of the text to the codebook definitions to determine the appropriate code or codes.

\section{Four Decades of Policy Advocacy}

Policy advocacy was demonstrated in 766 of the 1924 workshops. These workshops did not simply mention a policy, rather the purpose of the workshop was to drive policy. Four policy advocacy activities were present in the data and resembled the heuristic (or stages) model of the policy process: agenda setting, formulation, implementation, and evaluation (Sabatier 2007). Figure 1 presents the number of workshops for each of these stages in the policy process 1980-2019. Evaluation and Implementation were the most common policy stages discussed. Agenda setting was the third most common and was discussed at all but one biannual meeting. The percentage of total biannual meeting reports workshops focused narrowly on public policy and the breakdown of the four categories of policy advocacy is provided in Figure 2. 


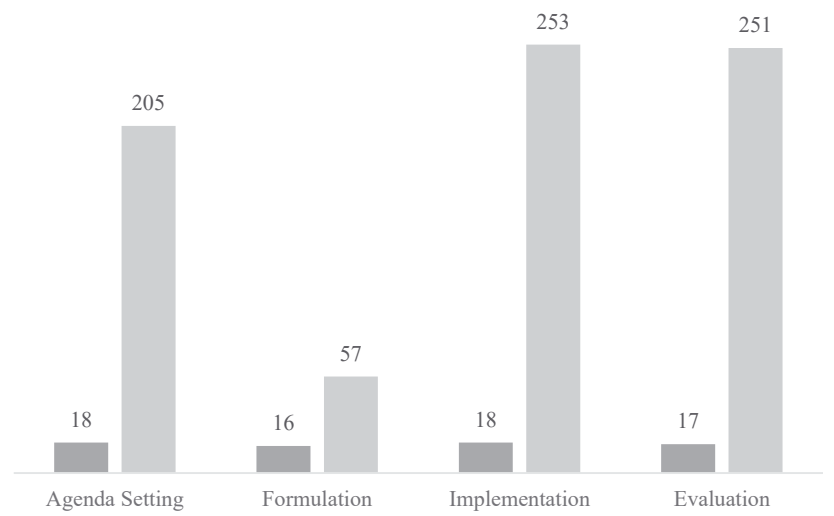

Figure 1: Frequency of policy advocacy discussions by stage in policy process, 1980-2019.

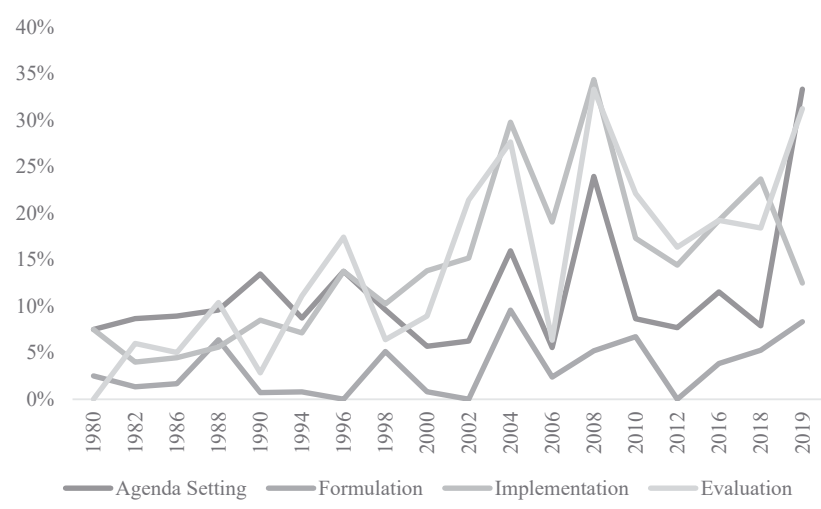

Figure 2: Percentage of discussions on public policy advocacy by stage in policy process, 1980-2019.

In the 41 years of national biannual meetings, the percentage of policy advocacy workshops ranged from 4 to $68 \%$ of total workshops, indicating that the priority of public policy emphasis varied over time. The remaining workshops focused on shelter management and enhancing direct services. The story of the variations in the timeline is told by the policy action the advocates were discussing. The data showed that policy implementation and policy evaluation were heavily emphasized two or three years following the passage and reauthorizations of each reauthorization of VAWA in 1994, 2000, 2005, and 2013.

Multiple stages in the cycle were often found in a single workshop such as this one, 
The presenter of this workshop will relate her experiences with our social and justice systems as she sought redress for being physically and mentally-abused [EVALUATION OF POLICY]. By addressing the abuse, she received at the hands of helpers [IMPLEMENTATION OF POLICY], this workshop can provide an opportunity to dialogue and to devise appropriate means of changing these systems [AGENDA SETTING].

Victim of Battery and Legalities, 1986

Here a victim shares her experience with existing policy through informal evaluation followed by discussion of policy solutions to guide future activism. At other times, multiple policies were presented in a single workshop. Like the 2008 workshop titled, VAWA, FVPSA, VOCA and Beyond where they discussed,

the good, the bad, and the ugly of the policy initiatives currently before Congress.

These three congressional acts, VAWA (1994), the Family Violence Prevention 1984, and the Victims of Crime Act (VOCA) (1984), play intricate roles in criminal and civil statute, rules for DV services and prevention, and DVAO funding. In this workshop, the presenters evaluate implementation barriers of previous authorizations and the formulation of the current reauthorizations, while exploring the intersection of multiple policies and funding streams directly impacting DVAOs.

As DV advocate roles became more specialized over time, so did the policyfocused workshops at the biannual meetings. For instance, in 2012, a workshop looked specifically at the most recent VAWA reauthorization that was stalled in Congress. For the first time since its original authorization in 1994, DV became a partisan issue, and workshop presenters called advocates to learn,

... solutions and/or strategies needed in the event this process becomes the norm for this bill or other bills.

Preserving Our Roots While Looking to the Future, 2012

Rather than looking broadly at DV policy, the presenters looked specifically at activism for a single bill essential to DVAOs and victims in the U.S.

\subsection{Areas of Policy Concern}

The attendees of this biannual event were mobilizable troops-nonprofit leaders, frontline staff, coalition partners, and individual members-who could be sent to the steps of Capitol Hill, the State House, and City Hall. NCADV directed this enormous resource towards four main policy areas specifically impacting victims of DV, 1) social welfare benefits, 2) professionalization of DVAO services, 3) criminal justice, and 4) civil justice. Figure 3 presents how implementation and 
evaluation of civil justice policy dominated policy advocacy. Civil justice is the most prevalent, which included issues such as protective orders and family court. Criminal justice policy heavily emphasized batterer accountability. Access to social welfare benefits, such as public housing and subsidized food programs, were scattered throughout the history of the event but were less common than criminal and criminal justice topics. While a hot topic for nonprofit managers throughout the 1990s and 2000s, professionalization of DVAO services was not frequently presented at this venue. Only 16 workshops in a total of seven biannual conferences addressed public policy related to the professionalization or certification of DVAO services. The data indicated that the coalition used this biannual meeting space to support victims and accessed other venues for policy work benefiting the DVAOs, rather than focusing on organizational maintenance and professionalization (Majic 2011). The coalition made use of its political resources where this long-term effort might be the most meaningful: the street-level. The locally-based organizations brought diversity to the policy goals and ensured social movement outcomes across venues through this close interaction and communication, an essential factor in social movement success (Arnold 2011; Van Dyke and Amos 2017).

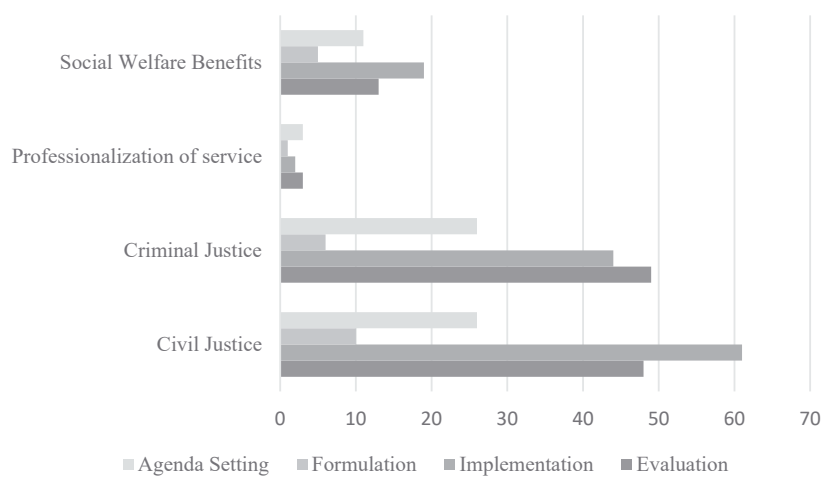

Figure 3: Frequency of policy issue addressed by stage of policy process, 1980-2019.

The coalition engaged its mobilizable troops across the U.S. to advocate for new policy or changes in current policy. By engaging at the national meetings, the coalition was able to work collectively at the local, state, and federal levels on multiple issues simultaneously. But how did the coalition engage with the policy process and maintain their resistance to bureaucratic influences within their member nonprofits? Further investigation into activity at each stage in the policy process shows evidence of the intentionality of this coalition. 


\subsection{The Many Roles of the Domestic Violence Victim Advocate}

The language used in the data described DV advocates as fierce warriors for the rights of those whose voices are muted. Their words are strong and unforgiving. They do not request policy shifts; they demand policy overhauls that support victims and hold batterers accountable. They are not represented by a single voice, but they speak as a collective voice. The author analyzed this behavior and the discourse patterns presented in each of the coded texts related to the policy cycle. Descriptive names for the roles the coalition played emerged from repeated language used in the texts. The coalition presented itself not as a policy advocate, as one may refer to them in scholarship. Instead, the representatives in the dataset used the language of activism, interpretation, enforcement, and questioning.

When advocates pushed policy issues onto the agenda, they spoke the language of activists. The Activist brought attention to current gaps in policy and sets the agenda. In the second role evident in the data, the Interpreter translated the specific needs of survivors as policy is formulated. The Interpreter translates the cries for help into policy language reflecting the policy beliefs of the coalition. Next, the Enforcer ensured that policy is implemented both in spirit and the manifest nature of the policy. Finally, the Questioner went to the table to evaluate policy. Whether the policy works well or fails, the Questioner gathers information and makes sure victims' voices are heard by policymakers. Coding took place at the sentence-level and as a result, some workshops received multiple codes. Workshops coded implementation or Enforcer were sometimes also coded evaluation or Questioner if barriers to implementation were solicited in a manner that the workshop facilitator intended to collect the information and provide it to policymakers or use it in future agenda setting activities. Consider this workshop on mandatory arrest laws,

The workshop will provide an overview of the [State Coalition's] statewide efforts in addressing the problem of [victims'] being arrested on multiple levels ... participants will be engaged in thoughtful discussion around issues of women being arrested that includes creating a basis for looking at this problem ... The workshop will guide advocates through a process of identifying concrete advocacy steps to engage in when working with women being arrested on multiple levels that include providing direct advocacy with the woman and systems advocacy ....

Radical Organizing for Change, 2004

The workshop offers a formal evaluation, solicits an informal evaluation, and assists with implementing the law as written. The four roles are evident throughout the lengthy history of the Coalition's activities. The evidence of these activities is presented next. 


\subsection{Activist: Setting the Agenda}

Agents for DVAOs, such as employees, volunteers, and contracted experts, see themselves as activists and advocates for change. They present the case of the person whose voice is muted by the abuser and the bureaucrat. They are the agenda setters. They take policy issues to Capitol Hill. In a 2000 workshop titled, "Organizing for Power," the session leader calls for attendees to,

Transform the women's anti-violence movement into one that builds collective power in order to gain equality and justice.

The presenter wants to move the agenda away from ending violence to an agenda of gaining power. Early workshops were comprehensive in nature as DV policy was just being formulated and implemented. With an emphasis on state policy, one session was designed

... to train participants to develop domestic violence legislation from the idea stage through drafting, political strategy and lobbying.

First National Conference Against Domestic Violence, 1980

Workshops were very straightforward, like the 1996 workshop titled, Forming NCADV's Legislative Agenda. The workshop agenda simply described the meeting as,

A brainstorming session to see where NCADV's membership wants us to go with federal legislation.

By the mid-1990s, NCADV and its members were comfortable with its role as the legislative advocate speaking for the Battered Women's Movement. The agenda for activism shifted to policy change rather than policy development when problems with existing policies became evident. In a 2004 workshop titled, "Cops who Batter and Kill," the speaker called for,

[new] policies to properly intervene in officer-involved domestic violence.

Policies to address DV had been around for nearly three decades by this point, but internal practices in police departments kept this class of offenders protected from accountability. Policy change was necessary for victim safety. DV advocates stood on the foundation of radical feminism and held close their role of activist. The coalition exchanged information with its troops and mobilized them towards new policy and policy change. Troops were sent to all levels of government to diffuse innovative policy through local- and state-level policy learning (Berry and Berry 2018). 
This is the traditional role of social movements: to push for policy change and policy adoption. These activities are reflective of what is known about social movement behavior (Edwards and McCarthy 2004; Soule and King 2006; Van Dyke and Amos 2017).

\subsection{Interpreter: Formulating Policy}

Interpreters translate one language to another to communicate a message when language barriers exist. The Interpreters filled this role by translating the expressed needs of victims at the street-level into policy language. To this end, NCADV set goals for their political activities in their planning meeting in 1978, such as

To monitor and impact legislation relating to domestic violence and family policy.

Biannual meetings with over one hundred workshops, each at 90 minutes in length, is not the appropriate venue for formulating detailed congressional bills. Thus, it came as no surprise that the stage of policy formulation was found far less frequently than the other policy stages among these biannual meeting agendas. Only 57 workshops were coded as policy formulation. This meeting was not a place for bill drafting. Rather, the event was a place to gather information about victims' needs from advocates in the field to translate into policy solutions. Legislative advocates held forums and 'speak outs' structured like round tables and focus groups to gain an understanding of the crises experienced by victims and their children and gather potential public policy solutions.

When early workshops for policy formation were held, the policy issue was broad: addressing the crime of DV. In 1986, a workshop simply titled, "Lobbying," guided advocates through the

Preliminaries to writing a bill, how to choose an author, when to organize a public hearing, how to follow a bill and help it through the process ...

Later, workshops shifted to information sharing and gathering format. In 2006, as economic self-sufficiency became a frequent topic at these biannual meetings and in public policy, a workshop was designed to help advocates take federal policy trends to the state and local levels.

... all too often, domestic violence can jeopardize victims' employment and housing. Advocates in many states have responded by passing legislation specifically addressing these needs ... Participants will discuss strategies and will receive model legislation, testimony, letters, and other supporting materials. 
Attendees interpret their local needs for the purpose of larger policy action. Housing and unemployment problems and solutions vary by locality. Advocates collectively meet with thousands of victims each year and hear the immediate needs in each area of the U.S. The mobilizable troops provide and solicit information, similar to the coalition behavior observed by Wiley, Searing, and Young (2021). The troops then connect with policymakers with the formal legal authority to make policy decisions reflecting the coalition's policy beliefs. The coalition engages in this activity on a much smaller scale, as evidenced by the smaller frequency of workshops devoted to policy formation. Overwhelmingly, social movement and coalition research emphasize policy change, including agenda setting and policy formulation. Here one can see that policy formation behavior is minor compared to efforts towards the other stages in the policy process, like what we've learned from Majic (2011) and Edwards and McCarthy (2004) but in contrast to Arnold (2011).

\subsection{Enforcer: Policy Implementation}

DVAOs and their agents play a leading role in implementing federal, state, and local policy (Wiley 2020; Wiley and Berry 2018). Enforcers take it upon themselves to ensure that policy is implemented in ways that place victim safety at the forefront and adhere to the spirit of the law. DVAOs not only implement policies within their organizational field, but DVAOs serve as enforcers for implementation activities for external entities as well. The word "enforcement" is applied because these workshops often were focused on ensuring others, such as the criminal justice system or welfare systems, knew the policy in question and provided equal and fair access to the benefits of that policy. Their forceful and expectant language articulated their role of policy enforcer.

A total of 188 workshops discussed or provided guidance on implementation. The first conference in 1980 opened with workshops on providing police training and accessing government benefits for battered women. Others were about ensuring accessing to federal housing funding. Leaders from the Battered Women's Movement facilitated these workshops with voices of entitlement to rights, benefits, and funding. Then in 1990, leaders and staff of DVAOs began sharing information with each other about holding helping agencies, such as criminal justice and welfare offices, accountable and bringing more services inhouse instead of depending on outside entities. Workshops such as, "Holding the System Accountable,” (The Battered Women's Movement in Action ... 1990 and Beyond, 1990) emerged. Teaching outside entities how to implement the law was 
no longer satisfactory. Advocates began to ensure that the policy was implemented properly, or they took on the duty themselves.

In 1998, workshops were held for monitoring police departments and the courts to ensure the law was adhered to. Here participants learn,

Supervisory skills which reinforce appropriate interventions and discourage inappropriate interventions such as dual arrests, filing false reports, etc. Participants will also be given information on monitoring procedures to assure local domestic violence policies are being implemented effectively at the street-level.

Working with Resistant and Reluctant Law Enforcement Officers, 1998

Advocates are provided with information and taught skills to enforce proper implementation of the law. Then at the biannual meeting in 2000, discussions emerged about pressuring courts to enforce legislation designed for "Getting Guns Out of Batterer's Hands" (The "Herstory” of Our Future: Creating Social Change, 2002) such as the Gun Control Act and VAWA. Advocates gain knowledge and skill,

... For achieving systemic reform on how jurisdictions enforce the firearm laws.

The Enforcer is happy with the current policy as written because it is the policy the coalition previously fought for and it aligns with the coalition's policy beliefs.

The high frequency of workshops related to enforcement reflects the demand for on-the-ground tools for policy implementation. This advocacy coalition armed its mobilizable troops with information while devoting its resources heavily towards policy implementation, moving away from familiar scholarly understandings of social movement and coalition behavior with few exceptions. For instance, Wiley, Searing, and Young found that coalitions worked to force policy implementation when the policy process stalled at policy adoption (2021). Majic identified oppositional implementation as a form of accountability enforced within social movements (2014). Whether the task is to enforce proper policy implementation or to block improper implementation, implementation is clearly central to this coalition's priorities.

\subsection{Questioner: Evaluating the Policy Effect}

Advocates are passionate about ensuring accountability of perpetrators, access to benefits rightly due to victims, and the survival of their organizations. They assiduously assess the value and functionality of policies impacting them. In this arena, advocates are Questioners. 
Problems to be discussed are the threats to our programs, our values and ourselves - funding cuts, restrictive family legislation, reduced AFDC and food stamps, reduced legal services and more conservative state legislatures. Questions to be discussed are when to fight the threats and how, when to compromise in order to survive, what strategies to use and how to decide.

End Violence in the Lives of Women, 1982

The rights and safety of victims of DV are never placed second on the priority list. They are paramount. When a public policy solution is working well, the coalition pushes for more. When the policy is not working, they ask questions. These actors connect at the biannual meeting to discuss the flaws in the systems and policies dictating their services. Formal policy evaluation is conducted externally and internally, but evaluations are also conducted informally day-to-day as advocates visit the local public offices such as courts, welfare systems, and public housing. They make strong claims such as,

The advent and implementation of new federal [housing] laws and policies have posed greater dangers for battered women...

Envisioning Our Future: Peace with Justice, 2000

The advocates evaluate the implementation of the manifest nature and the spirit of the law. When victims are in danger, the advocates help each other speak up and ask why.

Child custody was a common theme in the data because policy solutions include many coalition stakeholders and the policy continuously evolves. This early biannual meeting included a workshop not too different from more recent meetings.

Trends in custody law (joint custody, mediation, use of financial criteria, restrictions on custodial parent's right to move) are increasingly being used to the detriment of battered women and their children ... This session will educate participants about these trends and discuss possible solutions such as ligation, legislation, training, and other service strategies.

The Battered Women's Movement: Building a Non-Violent World, 1986

And then later,

It is well known that abusers will use any tools and opportunities available to them 'including the court system to continue abusing their victims. As part of a custody case, a court will often want to appoint a custody evaluator. A custody evaluation often provides the abuser a unique opportunity for continuing the abuse. He swears that he never harmed his victim and that she is mentally ill and makes false accusations against him. He is a convincing con artist, able to lie better than the victim can tell the truth. He can often con the custody evaluator into recommending custody to 


\begin{abstract}
him while, during the process, using it to further harass his victim in many ways. This workshop will present seven strong arguments participants can use to persuade the judge that a custody evaluation should not be ordered, thus depriving the abuser a weapon he can use against his victim.
\end{abstract}

In the 1986 workshop, the presenters look for tools for changing this insufficient policy. Later, they alert advocates of the problems in existing policy. Advocates identify what is wrong and offer street-level solutions. Having mobilizable troops engaging at the local courthouses and state houses gives the coalition insight into which policies are working and which ones are not. Centralizing this investigation into what is working and what is not helps legislative advocates identify the patterns and outcomes of such policies and then determine what changes are necessary. Questions are asked here. The answers are used to determine next steps. The coalition leverages its strongest resource to engage in a valuable and often ignored step in the policy process: policy evaluation. The coalition solicits information from the attendees and provides information to the attendees as well. Attendees participate in a give-and-take to determine the efficacy of policy wins, as this stage is often overlooked in social movement and coalition scholarship or is confused with agenda setting.

The roles of Activist, Interpreter, Enforcer, and Questioner remain pronounced over their four-decade history of gathering nationally to tackle DV. As is presented in Figure 4, meetings occurring pre-VAWA years, 1980-1994, exhibited each of the four advocate roles. In the immediate years following the first passage of VAWA, 1996-2010, proportionately the role of Activist and Interpreter decreased. This time period includes the greatest number of discussions about the role of Enforcer as it included the implementation of VAWA and the 2000 reauthorization and great shifts in welfare policy. Emphasis on the role of Enforcer could be indicative of how the Coalition saw itself: as responsible for ensuring DV policy is properly implemented. From 2011 to 2019, VAWA became a partisan issue as the policy named marginalized populations as policy priorities. The roles of policy advocacy became more evenly dispersed. The coalition shifted its resources towards more meaningful roles as the needs arose. By following coalition behavior beyond policy adoption, one can observe a continuous effort to ensure policy beliefs are upheld during implementation. Following policy through each stage of the process through ongoing interaction and communication at these events may be the substance that sustains this coalition (Van Dyke and Amos 2017). 


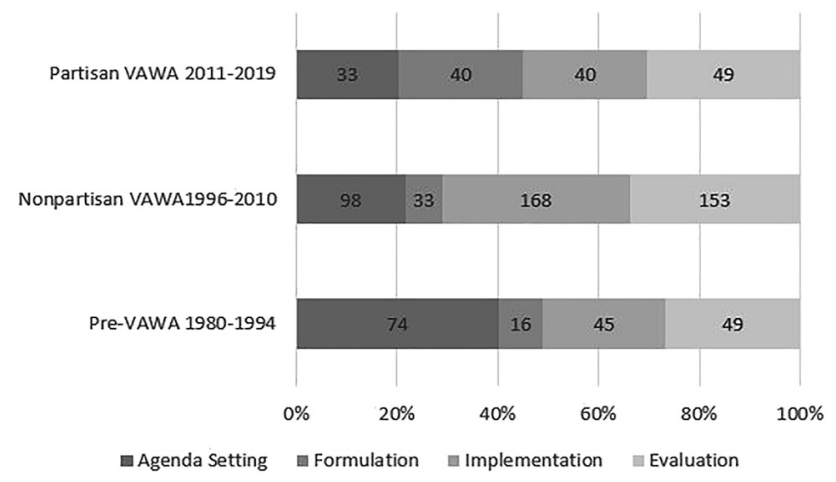

Figure 4: Percentage and frequency of stages of the policy process discussed across three legislative eras, 1980-2019.

\section{Discussion}

This advocacy coalition leveraged its political resources over time to affect policy implementation and evaluation through (1) continual engagement with their mobilizable troops, (2) deployment of information, and (3) maintenance of relationships with leaders and policymakers at all levels of government. Public opinion and pecuniary resources were not largely present in this analysis but did play a role in their ability to pursue policy goals. NCADV's biannual meetings provided the coalition access to four political resources: information, mobilizable troops, financial resources, and skillful leadership. As coalition goals were achieved, new goals emerged based the changes in the enhanced political resources. For instance, as mobilizable troops increased, they diversified and refocused. Information was transformed from the needs of victims into policy that was then shared with and by coalition members. The members professionalized and the coalition increased their legitimacy (Edwards and McCarthy 2004; Arnold 2011; Wiley 2020). Table 2 provides an interpretation of the coalition's resource usage, including operationalization of NCADV's unique resources, engagement level of the resource, and fluctuations in usage of resource over time.

For this coalition, policy advocacy occurred on a national scale while addressing policy concurrently at the federal, state, and local levels. The strength of this policy advocacy comes from the mass activity tied to NCADV's biannual meetings, supporting Arnold's finding that close social ties support long-term cooperation (2011). NCADV diffused advocacy costs across its membership of nonprofits by engaging across policy arenas, venues, and levels of government 
Table 2: NCADV's political resources.

\begin{tabular}{|c|c|c|c|c|}
\hline & $\begin{array}{l}\text { Mobilizable } \\
\text { troops }\end{array}$ & Information & Skillful leadership & $\begin{array}{l}\text { Financial } \\
\text { resources }\end{array}$ \\
\hline $\begin{array}{l}\text { Operationalization } \\
\text { of NCADV's Political } \\
\text { Resource }\end{array}$ & $\begin{array}{l}\text { Attendees at } \\
\text { biannual } \\
\text { meeting }\end{array}$ & $\begin{array}{l}\text { Policy needs and } \\
\text { experiences with } \\
\text { implementation } \\
\text { expressed at the } \\
\text { street-level; } \\
\text { Scholarship on } \\
\text { violence against } \\
\text { women }\end{array}$ & $\begin{array}{l}\text { Executive directors } \\
\text { at national coali- } \\
\text { tion, state co- } \\
\text { alitions, and } \\
\text { locally based } \\
\text { nonprofits }\end{array}$ & $\begin{array}{l}\text { Biannual } \\
\text { meeting fees } \\
\text { and member- } \\
\text { ship dues }\end{array}$ \\
\hline $\begin{array}{l}\text { Engagement Level } \\
\text { of Source (Weible } \\
\text { et al. 2020) }\end{array}$ & $\begin{array}{l}\text { Organization } \\
\text { and Coalition }\end{array}$ & Individual & Organization & Coalition \\
\hline $\begin{array}{l}\text { Fluctuations in us- } \\
\text { age of resource over } \\
\text { time (Nohrstedt } \\
\text { 2011) }\end{array}$ & $\begin{array}{l}\text { Organizations } \\
\text { began spinning } \\
\text { off NCADV in the } \\
\text { mid-1990s due } \\
\text { to (1) increase in } \\
\text { government } \\
\text { funding, (2) } \\
\text { disagreement } \\
\text { on taking gov- } \\
\text { ernment fund- } \\
\text { ing, and (3) } \\
\text { development of } \\
\text { expertise in } \\
\text { serving varia- } \\
\text { tions in the ser- } \\
\text { vice population } \\
\text { Early troops } \\
\text { shared radical } \\
\text { feminist views; } \\
\text { later troops had } \\
\text { varied policy } \\
\text { priorities and } \\
\text { were less radical }\end{array}$ & $\begin{array}{l}\text { Information } \\
\text { increased as vic- } \\
\text { tims' access to } \\
\text { services } \\
\text { increased; schol- } \\
\text { arship developed } \\
\text { over time as more } \\
\text { scholars exam- } \\
\text { ined the issue }\end{array}$ & $\begin{array}{l}\text { Leaders built } \\
\text { expertise in policy } \\
\text { advocacy as field } \\
\text { professionalized } \\
\text { beginning in the } \\
\text { 1990s }\end{array}$ & $\begin{array}{l}\text { Members } \\
\text { continued to } \\
\text { pay dues and } \\
\text { biannual } \\
\text { meeting atten- } \\
\text { dance } \\
\text { remained } \\
\text { steady until } \\
\text { the early } \\
2010 \text { s. }\end{array}$ \\
\hline
\end{tabular}

(Van Dyke and Arnold 2017); however, over time they shifted their resources from pushing policy change to maintaining their policy wins. By addressing numerous social issues concurrently, they were able to appease their diverse membership.

The roles of the coalition in each stage are distinct and due to its large membership and wide political reach these roles overlap. Domestic violence policy spans criminal, welfare, health, and foreign affairs policy domains. Thus, the 
coalition's policy reach is vast. First, the coalition sets the political agenda from the federal level to the local level. Once the issue is placed on the legislative agenda, the coalition formulates policy. The coalition ensures proper implementation once the policy is adopted. Finally, the coalition evaluates the efficacy of the policy to meet the coalition's policy goals and that the policy is in line with the coalition's policy beliefs. NCADV demonstrated how a coalition can simultaneously work across governmental levels and policy domains. Single issue coalitions can learn from NCADV how to expand their policy reach over time. The coalition's age served as a strength as it allowed for continual conversation and iterations of the policy process over four decades. Smaller and younger coalitions may not be able to immediately experience such strength but they can learn from the early years of the coalitions focus on agenda setting and then their transition to ensuring proper policy implementation.

These findings contributes to ACF scholarship by providing a clearer understanding of a coalition's deployment of its resources. Weible et al. posed the question, "how and to what extent do coalitions capitalize on new resources to achieve greater influence in policy subsystems?” (2011, p. 357). The data demonstrated that resources were actively engaged at each stage in the policy process and made progress toward policy goals. The findings support the work of Wiley, Searing, and Young (2021): coalitions engage their political resources in policy advocacy during implementation efforts. In their study of nine advocacy coalitions, information was the priority resource because it was the most plentiful and advantageous for their advocacy goals. Similarly, the NCADV leaned on its most plentiful resource, mobilizable troops, while deploying information and accessing formal legal authority for support in policymaking (Van Dyke and Amos 2017). Nohrstedt also found that the value of the coalition resource was dependent upon the particular advocacy needs in his study of two opposing coalitions (2011). A causal or hierarchical relationship between coalition resources and policy change may not be important for further establishing their role in ACF. What may be more important than how coalitions use resources is when coalitions deploy resources: Coalitions align their most plentiful resources to target the next stage in the policy process necessary to achieve their policy goals.

This exploration of social movement borne nonprofits expands our insight into the leveraging of resources following a successful social movement. The harnessing of resources across levels of government and geographic boundaries reflects the actions of a social movement while the formalization and shared belief systems reflect a coalition. When social movements formalize into organizations, the coalition strengthens. The coalitions maintain their resources and develop new resources through this formalization. This is evidenced in the Battered Women's 
Movement (Arnold 2011) and NCADV. To better understand coalitions, scholars must look toward their activities beyond a single policy change event.

\section{Conclusions}

The advocacy coalition framework is typically used to explain coalition activity driving policy change. ACF was developed because the heuristic model of policy process is a flawed breakdown of policymaking (Sabatier 2007). The data in this study evidenced an intersection between implementation and evaluation as well as between agenda setting and formulation. The policy stages were not independent but using the heuristic model for coding purposes was helpful in interpreting coalition behavior. NCADV engaged more of its resources following policy change. The heuristic model illuminated this finding and our understanding of how this coalition behaved differently than what is predicted in the literature.

The advocacy coalition framework was not developed to explain advocacy behavior beyond policy change. Accordingly, alternate explanations for these findings exist. First, the policy actors may have been engaging independently on behalf of their home organizations. Professional associations contract with legislative advocates and many of their member organizations contract with lobbyists rather than the nonprofit employees or volunteers advocating directly with policymakers. The organizations could view the NCADV biannual meeting as an effective place to reach their audience but are not choosing to act collectively. Second, Post argues organizations form alliances to "increase access to the policy process." (2015, p. 286). Organizations may be forming smaller alliances among their peers and using the NCADV biannual meetings as a meeting location. Third, as organizations spun off NCADV, they may have begun to act more to benefit their own new missions. Only $40 \%$ of the workshops at the events were oriented to policy advocacy. Policy advocacy may simply be a side activity to attract a wider audience at these events rather than a central motive. Despite these alternate expectations, the discourse in the workshop descriptions would indicate a more collective intention to both drive and enforce policy change.

From NCADV, the field can better understand how coalitions may engage collectively in politicly charged issues. Framing nonprofit political activity across the stages of the policy process can open doors to better use of scarce political resources. First, coalitions should push for policy change aligning with their policy beliefs and then ensure the policy is implemented properly. These policy activities can take place simultaneously over time where actors can engage in various policy issues in multiple stages of the policy process. Coalitions of social movement borne 
nonprofits can shift their political approach once a policy change occurs and ensure implementation aligns with coalition's policy beliefs.

\section{Appendix: Example of coding strategy}

\begin{tabular}{|c|c|c|}
\hline Code name & Code description & Coded example \\
\hline Agenda setting & $\begin{array}{l}\text { These workshops include policy ideas } \\
\text { and policy needs. The workshop may } \\
\text { propose an idea for new policy or a } \\
\text { change in policy; prioritize one issue } \\
\text { over another; solicit policy proposals. }\end{array}$ & $\begin{array}{l}\text { Title: Federal Legislative Initiatives: } \\
2000 \text { And Beyond } \\
\text { Description: Please join the National } \\
\text { Coalition Against Domestic Violence's } \\
\text { Public Policy Office staff in a discussion } \\
\text { about the legislative initiatives pres- } \\
\text { ently before the United States Congress } \\
\text { that would impact your work and the } \\
\text { lives of all battered women and their } \\
\text { children. This is an opportunity to } \\
\text { discuss the obstacles, challenges and } \\
\text { successes you have experienced while } \\
\text { working with domestic violence survi- } \\
\text { vors, and a chance to brainstorm about } \\
\text { future federal legislative needs. Come } \\
\text { ready with ideas for further federal } \\
\text { intervention and let us know how we can } \\
\text { continue to best represent the needs of } \\
\text { all women to your elected officials in } \\
\text { Washington. (2000) }\end{array}$ \\
\hline Formulation & $\begin{array}{l}\text { These workshops include or solicit } \\
\text { new or edited policy language. They } \\
\text { may include development of the lan- } \\
\text { guage that will be included in the } \\
\text { proposed legislation. }\end{array}$ & $\begin{array}{l}\text { Title: Domestic Violence Advocacy and } \\
\text { Training with Law Enforcement } \\
\text { Agencies } \\
\text { Description: The presenters will } \\
\text { discuss several approaches for domes- } \\
\text { tic violence programs to use in advo- } \\
\text { cating with law enforcement agencies: } \\
\text { 1) Training (establishing contacts, con- } \\
\text { tent, resources), 2) Policy formation/ } \\
\text { revisions (local, statewide, sample pol- } \\
\text { icies), 3) Legislation (California experi- } \\
\text { ence), 4) Getting paid for training, and } \\
\text { 5) Lawsuits (as a last resort; examples } \\
\text { of state cases). (1986) }\end{array}$ \\
\hline Implementation & $\begin{array}{l}\text { These workshops include existing } \\
\text { policies. Guidance is offered for } \\
\text { ensuring the policy is being applied }\end{array}$ & $\begin{array}{l}\text { Title: Working with Resistant and } \\
\text { Reluctant Law Enforcement Officers } \\
\text { Description: This workshop will cover }\end{array}$ \\
\hline
\end{tabular}


(continued)

\begin{tabular}{|c|c|c|}
\hline Code name & Code description & Coded example \\
\hline & $\begin{array}{l}\text { with the manifest nature and spirit of } \\
\text { the legislation in mind. }\end{array}$ & $\begin{array}{l}\text { training, supervision, and monitoring of } \\
\text { police officers who intervene in domes- } \\
\text { tic violence cases. Participants will } \\
\text { learn methods which discourage victim } \\
\text { blaming and encourage officers to be } \\
\text { more sensitive. Participants will learn } \\
\text { supervisory skills which reinforce } \\
\text { appropriate interventions and } \\
\text { discourage inappropriate interventions } \\
\text { such as dual arrests, filing false re- } \\
\text { ports, etc. Participants will also be } \\
\text { given information on monitoring pro- } \\
\text { cedures to assure local domestic } \\
\text { violence policies are being imple- } \\
\text { mented effectively at the street-level. A } \\
\text { veteran battered women's advocate } \\
\text { and a veteran police officer will discuss } \\
\text { their experience working with law } \\
\text { enforcement officers over the past } 20 \\
\text { years. They will also conduct participa- } \\
\text { tory exercises to enhance management } \\
\text { skills. Training designs, supervisor } \\
\text { checklists and case monitoring forms } \\
\text { will be distributed. (1998) }\end{array}$ \\
\hline Evaluation & $\begin{array}{l}\text { These workshops include existing } \\
\text { public policies. Questions discussed } \\
\text { might include, is this policy working? } \\
\text { what are the policy outcomes? what } \\
\text { do we think about this policy now that } \\
\text { it has passed? }\end{array}$ & $\begin{array}{l}\text { Title: Mandatory Arrest: Does It Work? } \\
\text { How and Why? } \\
\text { Description: This workshop will } \\
\text { examine Connecticut's experience with } \\
\text { comprehensive domestic violence } \\
\text { legislation. which mandated arrest and } \\
\text { provided court-based intervention and } \\
\text { referral programs. The workshop will } \\
\text { explore the pragmatic and strategic } \\
\text { aspects of designing and implementing } \\
\text { such a policy and will describe evalua- } \\
\text { tion research that examines whether the } \\
\text { law is meeting our expectations for } \\
\text { fairness and effectiveness. (1990) }\end{array}$ \\
\hline
\end{tabular}




\section{References}

Albright, E. A. 2011. "Policy Change and Learning in Response to Extreme Flood Events in Hungary: An Advocacy Coalition Approach.” Policy Studies Journal 39 (3): 485-511.

Arnold, G. 2011. "The Impact of Social Ties on Coalition Strength and Effectiveness: The Case of the Battered Women's Movement in St Louis." Social Movement Studies 10 (02): 131-50.

Arnold, G., and J. Ake. 2013. "Reframing the Narrative of the Battered Women's Movement." Violence Against Women 19 (5): 557-78.

Berry, F. S., and W. D. Berry. 2018. "Innovation and diffusion models in policy research." In Theories of the Policy Process, Vol. 169, edited by C. M. Weible and P. A. Sabatier. New York, NY: Routledge, 5.

Bowen, G. A. 2009. “Document Analysis as a Qualitative Research Method.” Qualitative Research Journal 9 (2): 27-40.

Creswell, J. W. 2012. Qualitative Inquiry and Research Design: Choosing Among Five Approaches, 3rd ed. Los Angeles: SAGE Publications, Inc.

Dragiewicz, M. 2008. "Patriarchy Reasserted Fathers' Rights and Anti-VAWA Activism." Feminist Criminology 3 (2): 121-44.

Edwards, B., and J. D. McCarthy. 2004. "Resources and Social Movement Mobilization.” The Blackwell Companion to Social Movements 116-52.

"End Violence in the Lives of Women Second National Conference and National Meeting" 1982. National Meeting Agenda. Milwaukee: National Coalition Against Domestic Violence.

Family Violence Prevention and Services Act of 1984. 1984. Family Violence Prevention and Service.

Hsieh, H.-F., and S. E. Shannon. 2005. “Three Approaches to Qualitative Content Analysis.” Qualitative Health Research 15 (9): 1277-88.

Ingold, K. 2011. "Network Structures within Policy Processes: Coalitions, Power, and Brokerage in Swiss Climate Policy." Policy Studies Journal 39 (3): 435-59.

Jenkins-Smith, H. C., D. Nohrstedt, C. M. Weible, and K. Ingold. 2018. "The Advocacy Coalition Framework: An Overview of the Research Program." In Theories of the Policy Process, edited by C. M. Weible, and P. A. Sabatier. New York: Routledge, https://doi.org/10.4324/ 9780429494284-5.

Jones, M. D., and H. C. Jenkins-Smith. 2009. "Trans-Subsystem Dynamics: Policy Topography, Mass Opinion, and Policy Change.” Policy Studies Journal 37 (1): 37-58.

Kleidman, R., and T. R. Rochon. 1997. "Dilemmas of Organization in Peace Campaigns." In Coalitions \& Political Movements: The Lessons of the Nuclear Freeze, edited by T. R. Rochon, and D. S. Meyer, 47-60. Boulder: L. Rienner.

Libby, P. 2012. “Lobbying and Advocacy what Does it Mean, and Why Should You Do it?" In The Lobbying Strategy Handbook 10 Steps to Advancing Any Cause Effectively, edited by P. Libby. Thousand Oaks: SAGE Publications.

Lobbying | Internal Revenue Service. n.d. https://www.irs.gov/charities-non-profits/lobbying (accessed December 11, 2019).

Majic, S. 2011. "Serving Sex Workers and Promoting Democratic Engagement: Rethinking Nonprofits' Role in American Civic and Political Life.” Perspectives on Politics 9 (4): 821-39. Majic, S. 2014. Sex Work Politics. Philadelphia: University of Pennsylvania Press. 
“Measuring Lobbying Activity: Expenditure Test | Internal Revenue Service.” n.d. https://www.irs. gov/charities-non-profits/measuring-lobbying-activity-expenditure-test (accessed December 11, 2019).

“National Coalition Against Domestic Violence." 2019. About Us. 2019 https://ncadv.org/about-us. Nohrstedt, D. 2011. "Shifting Resources and Venues Producing Policy Change in Contested Subsystems: A Case Study of Swedish Signals Intelligence Policy." Policy Studies Journal 39 (3): 461-84.

Nohrstedt, D., and C. M. Weible. 2010. "The Logic of Policy Change after Crisis: Proximity and Subsystem Interaction.” Risk, Hazards \& Crisis in Public Policy 1 (2): 1-32.

Nowell, B., and K. Albrecht. 2019. "Reviewer's Guide to Qualitative Rigor | Journal of Public Administration Research and Theory | Oxford Academic." Journal of Public Administration Research and Theory 29 (2): 348-63.

Onwuegbuzie, A. J., and N. L. Leech. 2007. "Validity and Qualitative Research: An Oxymoron?" Quality and Quantity 41 (2): 233-49.

Pierce, J. J., H. L. Peterson, M. D. Jones, S. P. Garrard, and T. Vu. 2017. "There and Back Again: A Tale of the Advocacy Coalition Framework." Policy Studies Journal 45 (S1): S13-46.

Post, M. A. 2015. "Multi-Organizational Alliances and Policy Change: Understanding the Mobilization and Impact of Grassroots Coalitions." Nonprofit Policy Forum 6 (3): 286.

Pralle, S. B. 2003. "Venue Shopping, Political Strategy, and Policy Change: The Internationalization of Canadian Forest Advocacy." Journal of Public Policy 23 (3): 233-60.

Rosen, L. N., M. Dragiewicz, and J. C. Gibbs. 2009. “Fathers' Rights Groups: Demographic Correlates and Impact on Custody Policy." Violence Against Women, https://doi.org/10. $1177 / 1077801209331409$.

Sabatier, P. A. 2007. "The Need for Better Theories." In Theories of the Policy Process. 2nd ed. edited by P. A. Sabatier, 3-17. Boulder: Westview Press.

Sabatier, P. A., and C. M. Weible. 2007. "The Advocacy Coalition Framework: Innovations and Clarifications." In In Theories of the Policy Process, edited by P. A. Sabatier Second, 189-220.

Smith, A. 2007. "The Revolution Will Not Be Funded." In The Revolution Will Not Be Funded: Beyond the Non-profit Industrial Complex, edited by INCITE! Women of Color Against Violence, 1-18. Cambridge: South End Press.

Soule, S. A., and B. G. King. 2006. "The Stages of the Policy Process and the Equal Rights Amendment, 1972-1982." American Journal of Sociology 111 (6): 1871-909.

Temporary Assistance for Needy Families 1996, vol. 42, 601. U.S.C.

Van Dyke, N., and B. Amos. 2017. "Social Movement Coalitions: Formation, Longevity, and Success." Sociology Compass 11 (7): e12489.

Victims of Crime Act of 1984. 1984. 2 U.S.C.A. $§ 10601$.

Violence Against Women Act of 1994. 1994, Vol. 18. ENR. U.S.C. 2265. http://thomas.loc.gov/cgibin/query/z?c103:H.R.3355.

Weible, C. M. 2007. "An Advocacy Coalition Framework Approach to Stakeholder Analysis: Understanding the Political Context of California Marine Protected Area Policy." Journal of Public Administration Research and Theory 17 (1): 95-117.

Weible, C. M., P. A. Sabatier, and K. McQueen. 2009. "Themes and Variations: Taking Stock of the Advocacy Coalition Framework.” Policy Studies Journal 37 (1): 121-40.

Weible, C. M., K. Ingold, D. Nohrstedt, A. D. Henry, and H. C. Jenkins-Smith. 2020. "Sharpening Advocacy Coalitions." Policy Studies Journal 48 (4): 10854-81. 
Weible, C. M., P. A. Sabatier, H. C. Jenkins-Smith, D. Nohrstedt, A. Douglas Henry, and P. deLeon. 2011. "A Quarter Century of the Advocacy Coalition Framework: An Introduction to the Special Issue." Policy Studies Journal 39 (3): 349-60.

Wiley, K., and F. Berry. 2018. "Compassionate Bureaucracy: Assuming the Administrative Burden of Policy Implementation.” Nonprofit and Voluntary Sector Quarterly 47 (4S): 55S-75S.

Wiley, K. K. 2020. "Implementing Domestic Violence Policy: When Accountability Trumps Mission." Affilia: Journal of Women and Social Work 35 (4): 533-51.

Wiley, K. K., E. Searing, and S. H. Young. 2021. "The Utility of the Advocacy Coalition Framework in a Regional Budget Crisis." Public Policy and Administration 36 (3).

Yin, R. K. 2014. "Validity and Generalization in Future Case Study Evaluations." Evaluation 19 (3): 321-32. 